\title{
Chinese cultural view, the inner idea of Confucianism and the intuitionism of the Taoist school-comments on The Silver Wings: a scholarly sequel to the Golden Wing
}

\section{Du Jing}

Received: 8 April 2020 / Accepted: 3 June 2020 / Published online: 23 June 2020

(C) The Author(s). 2020 Open Access This article is licensed under a Creative Commons Attribution 4.0 International License, which permits use, sharing, adaptation, distribution and reproduction in any medium or format, as long as you give appropriate credit to the original author(s) and the source, provide a link to the Creative Commons licence, and indicate if changes were made. The images or other third party material in this article are included in the article's Creative Commons licence, unless indicated otherwise in a credit line to the material. If material is not included in the article's Creative Commons licence and your intended use is not permitted by statutory regulation or exceeds the permitted use, you will need to obtain permission directly from the copyright holder. To view a copy of this licence, visit http://creativecommons.org/licenses/by/4.0/.

\begin{abstract}
The Silver Wings: Local Society and Cultural Changes in China (1920s1980 s) is a representative ethnographic work since the reconstruction of Chinese anthropology in the late 1970s. It used the perspective of cultural change to make a return visit to the field sites described in the book "The Golden Wing". What is most academic valuable about the book is its methodological implications. To be specific, the book refers to the concept of "culture" in Chinese historical documents, putting the issues examined into the framework of the relationship between state and local society in the long course of Chinese history. In the field work, the author's use of intuitive research methods and the look-back method is also commendable. If we want to understand this book exactly, it is best to combine the two films the author made, Dragon Boat Festival and winter solstice, because they form a semantic chain. In short, The Silver Wings is an excellent work of anthropology, it had lead Chinese cultural anthropology into a new historical period.
\end{abstract}

\footnotetext{
D. Jing $(\bowtie)$

China Center for Legal Anthropology, Qingdao University, Qingdao, Shandong Province, P. R. China e-mail: dujing6619@sina.com
} 
Keywords The silver wings - Chinese family-lineage system - The concept of culture in the Chinese history - The framework for the analysis of state-local social relations · Cultural intuition $\cdot$ The look-back method

\section{Abbreviations \\ P. R. China: People's Republic of China \\ PHD: $\quad$ Doctor of Philosophy}

The Golden Wing: A Sociological Study of Chinese Familism, is an ethnographic work published by Lin Yueh-hwa (林耀华) in the 1940s. It tells the life history of a Han family in Fukien, China (Lin Yueh-hua, 1947). The Golden Wing plays an important role in the history of cultural anthropology in China and abroad. Not only has it laid the foundation for the research on Han society in China, but it provides a must-read bibliography of China studies, or Sinology, and an important window for the world to understand China.

The Silver Wings: Local Society and Cultural Changes in China (The Golden Wing Community of Lin Yueh-Hwa 1920s-1980s) (Zhuang Kongshao, 2000), is a follow-up observation of a return visit to the family and local society described in The Golden Wing. The author, Zhuang Kongshao (庄孔韶), is an outstanding disciple of Mr. Lin Yueh-hwa. Before the English edition of The Silver Wings was published by Los Angeles Ethnographics Press in 2018, the Chinese edition of the book was first published as a laureate edition in Taiwan in 1996, and then two other Chinese editions were printed, proving to be among the most influential works in the Chinese academic circle. It is a representative work of the reconstruction of the anthropology of China, from which we can get a glimpse of the achievements and rising standards of Chinese anthropology in China in the past 40 years.

In the winter of 1934, Lin Yueh-hwa returned to his hometown, Lingwei village (岭尾村) in Gutian county, Fukien, a village that had been called "Hwang village" (黄村) in The Golden Wing. He was extremely surprised at the change in fortunes of the two families featured in The Golden Wing: one prospered and the other languished in a short span of 20 years, though originally both families on equal footing. There was an affinity between the two families. One of the families was Lin's own, led by his own father, after whom The Golden Wing's Hwang Dunglin (黄东林) was modeled. The other family was Lin Yueh-hwa's father's elder sister's, led by Chang Fenchou (Lin Yueh-hwa's father's brother-in-law). Local people use the theory of “wind and water" (风水) or fengshui to interpret the ups and downs of different families, but Lin Yueh-hwa, trained in modern social science, would certainly not accept their opinions. Therefore, from the perspective of social anthropology, he examined his family history in the framework of local society and its historical context. More precisely, The Golden Wing covers a time span from the Revolution of 1911 to the Japanese invasion of China, and involves scenes from villages to towns, from towns to cities. It places the activities of families and their characters on the stage while involved in activities from agriculture to commerce, and from economy and culture to local politics. At the same time, The Golden Wing places great emphasis on the examination of human relations, for example, agnation, affinity, and social relations other than kinship, etc. Through an anthropological survey of the families in The Golden 
Wings, the author recognizes that the system of human relations is in a constant state of balance, or equilibrium. This equilibrium is often disturbed by external forces at any time, until a new equilibrium is later established. In the author's words, "Human life swings between balance and disturbance, between equilibrium and disequilibrium." (Lin Yueh-hwa, 1947: 225) This is a very wise interpretation of Eastern philosophy, which has a kind of transcendental vision. As Luo Guanzhong (罗贯中), the author of The Romance of The Three Kingdoms (Sanguoyanyi, 三国演义) said, “A kingdom will be separated when it has been united for a long time; and in turn reunited when it has been a long-time separated." (Luo Guanzhong, 2010:1).

In the late 1970s and early 1980s, Zhuang Kongshao studied the patriarchal clan commune system for his master's degree in ethnology under Professor Lin Yueh-hwa. During this period, professors taught evolutionism and the paradigm of Soviet ethnology, ${ }^{1}$ but the study of the patriarchal clan commune fostered Zhuang's interest in the later study of the Han family-lineage system. Many scholars mistakes The Silver Wings for his doctoral thesis, but it is not. In the mid and late 1980s, Zhuang continued to study for his doctoral degree under the tutelage of Mr. Lin Yueh-hwa. During his doctoral studies, he did two main things. First, he conducted research on educational anthropology, at topic related to work completed by other members of his family. Zhuang Ze-xuan (庄泽宣), the younger brother of Zhuang Kongshao's grandfather, was a famous educator during the period of the Republic of China. In the 1920s and 1930s, he carried out research on Ethnic Pedagogy at Sun Yat-sen University (中山大学). The study of ethnic education later became Zhuang Kongshao's doctoral dissertation, which can be regarded as a continuation of Zhuang Ze-xuan's research interest. It reflects the continuity of a family's academic pursuits. The second thing he did during his doctoral studies was revisit the families featured in The Golden wings in Lingwei village, and observe the regional society. From 1986 to 1989, Zhuang conducted five field surveys over the course of 14 months. More than 400 people were interviewed, including the descendants of The Golden Wing's subjects.

Later, Zhuang worked as a postdoctoral fellow in the department of anthropology at the University of Washington, USA, where he wrote The Silver Wings. In fact, the two studies are closely related: the study of educational anthropology made Zhuang Kongshao concerned about the enculturation of Confucianism at the grassroots level in China. This will be discussed below.

The Silver Wings examines the changes of fortune for the family in The Golden Wing, and the transformation of local society in the twentieth century. To be specific, it includes not only the Republic of China period, but also the Maoist and post-Maoist eras in the People's Republic of China, up until 1990. The content involves the family and lineage system, various religions (e.g., Taoism, Christianity, and local beliefs), the influence of gentleman and soldiers in the local society, the interaction between the state and the local people, etc. Among these topics, the impact of the grand narrative of Communist China on the local society and the response from the grassroots is the focus

\footnotetext{
${ }^{1}$ In 1984, he collaborated with professor Lin Yueh-hwa and published" a study on the morphology of patriarchal family commune"(《父系家族公社形态研究》, 青海人民出版社, 1984). This theoretical paradigm can be found in his book.
} 
of the investigation. In the study of Chinese society, the author tries to find a new explanatory theory and methodology through this ethnographic work.

The Silver Wings is groundbreaking in the field of cultural anthropology and has made various academic achievements. Here are some of the key points: In the first half of the twentieth century, some scholars divided China's social and cultural anthropology into the "northern" and the "southern" schools of thought (Tang,1976; Huang, 1983). The "northern School" is mainly represented by the Department of Sociology of Yenching University (燕京大学), led by Wu Wentsao (吴文藻), Li an-che (李安宅), Fei Hsiao-tung (费孝通), Lin Yueh-hwa and Martin. C. Yang (杨㻑春), etc. This academic community advocates the study of structural functionalism and needsfunctionalism. The "south school" is also known as the historical school or historicalanthropology school, with its center of influence being in The Institute of History and Philology, Academia Sinica (中央研究院历史语言研究所), based in Nanjing, China. Of course, the relevant teaching and research units of Xiamen University (厦门大学) and Sun Yat-sen University are also important bases of the southern school. Although the northern school's research orientation has made progress compared with evolutionism and culture-circle theory or cultural communication theory, seen in the context of the history of anthropology, it has some shortcomings. The main crux of structural functionalism and needs-functionalism is to make a static observation of a society and culture, with an emphasis on objective research. Scholars in this school of thought see the village and family-lineage as a functionally self-sufficient unit.

From the 1950s to the early 1980s, cultural anthropology in China was deeply influenced by the ethnological paradigm of the Soviet Union, highlighting the values of Marxism while cutting off the bilateral interaction between Chinese anthropology and its mainstream of Western counterpart. Since the mid and late 1980s, the revived anthropology in China has been able to restart its interaction with the European and American anthropology. The Silver Wings is a work born from this background. Of course, the writing of The Silver Wings is also a farewell to the author's past.

On the whole, The Silver Wings breaks through the barrier of functionalism from two dimensions. First, it revisited the Huang family of The Golden Wing from the perspective of cultural change, breaking the static structural research tendency (although The Golden Wing adopted the popular balance theory popular at that time); second, it put the research issues in a narrative framework related to both the nation and local society, breaking through the limitations of taking a community as a functionally self-sufficient unit. Before that, in both Skinner's market model and Freedman's research on Chinese lineages, theory of state and local society have always concerned about the relation or interaction between the nation and local people. Therefore, in an objective sense, "The Silver Wings" is a continuation of this research, though this is only a kind of coincidence, and not the author's explicit theory consciousness. The author's concern about the relationship between the state and local society is the result of looking at the problem from Zhuang's perspective of "the contact between great traditional and little tradition".

In his early years, Lin Yueh-Hwa realized that the lineage system practiced by Chinese peasants was derived from the Confucian elite of the past and was driven by the empire. Zhuang Kongshao inherited his teacher's thought. Naturally, this academic orientation also quietly avoided the popular Soviet ethnological paradigm 
popular in the Mao era. Until now, The Silver Wings has been at the forefront of a large number of studies in this direction. "Cultural change" and "the relationship between the nation and the local society" have become two core issues of concern to Chinese anthropologists. Therefore, The Silver Wings is the work of the times guiding the development direction of Chinese anthropology.

Anthropology was introduced to China in the late nineteenth century, and is considered an "imported discipline". Since the 1930s, anthropologists in China have tried to explore a path of localization. As a result, in different periods, there were three groups of anthropologists who have made more influential explorations. The exploration of the first group took place in the 1930s and was discussed by Sun Benwen (孙本文), Huang Wenshan (黄文山), Li Chi (李济), Wu Wentsao, Cen Chiawu (岑 家梧), and Ma Changshou (马长寿), etc. These scholars had three different opinions: the first explored the use of the foreign anthropological methods by selecting the good ones and integrating them into Chinese anthropology according to the actual situation in China; the second proposed to adopting the anthropological theory of a particular foreign school thought as a blueprint or chief source to realize the Sinicization of anthropology; the third one emphasized the particularity of China's reality, and advocated the absorption of the rationale behind foreign anthropological theory, to better observe and study Chinese society (Wang Jianmin, 1997: 276-290).

The second group's exploration took place in Taiwan province in the 1970s, represented by the team following the "Zhuoxi and Daduxi River Basin Research Plan” (“浊大计划”) led by Chang Kwang-chi (张光直). This group tried to explore China's anthropological path through multi-disciplinary participation, with emphasis on the combination of China's traditional Sinology, history, and Western anthropology (Wang Jianmin, etc. 1998: 288).

The anthropological study of Taiwan Yuanzhumin (ethnic minority peoples) began in the 1950s by former mainland anthropologists (for example, Ling Chunsheng, Du Erwei, Rui Yihfu, Wei Huilin, etc.) who migrated to Taiwan and whose continued research initiated the study of Austronesian languages (Nandaoyuxi, 南岛语系) society. Taiwan scholars (for example, Chen Shaoxin, Liu Zhiwan, Chen Qilu, Tang Meijun, Li Yiyuan, etc.) undertook numerous localized studies on Chinese society. However, they initially lacked clear reflection on and pursuit of localization theory as the independent means and strategy of anthropology in China.

The third group's exploration took place in the last 20 years of the twentieth century, and was represented by Fei Hsiao-tung and Li Yiyuan (李亦园), who emphasized the value of Chinese experience to the development of Chinese anthropology (Wang Jianmin, Zhang Haiyang, Hu Hongbao, 1998: 303-311). The appeal of localization actually reflects that Chinese anthropologists' dissatisfaction with the simple transplantation of anthropology from the West and desire to avoid the dependence on Western theories.

It can be said that, on the basis of being the succeeding to the thinking of Lin Yuehhwa's The Research of Yixu Lineage (Lin Yueh-hwa, 2000) and The Golden Wing, Zhuang Kongshao's The Silver Wings has taken a unique searching road in the search for the sinicization of the academic. It has successfully adopted the China's native concept of "culture" (wenhua, or yiwenhuazhi, 文化或以文化之), including the concept of "Pass-Through Moralization (guohua, 过化)" (Zhuang Kongshao, 2012, 2020). In classical Chinese literature, the so-called "culture" means "civilizing the masses 
ostensibly with Confucianism classics, etiquette system, and thoughts". The ancient Confucian scholars for a variety of reasons arrived or passed through various places and spread Confucianism and system. This process is called "guohua". This is a kind of cultural practice from the top to the bottom to make people think and act in accordance with Confucian requirements, thus becoming civilized and morally literate. For thousands of years, the history of Chinese culture in practice was indeed completed under the guidance of the upper class or the elite, while the voices and demands of local people and grassroots forces were often ignored. Common people had always been disciplined and guided by the empire and the great tradition, but the Confucianization of the Golden Wing family and their lineage in the local society differs from that found in traditional time, which was very rooted in nepotism or kin selection, and which met the wishes of the primordial attachment of local people. The author of Silver Wings generalizes this kind of traditional cultural practice process into four links: philosophers' invention, statesmen's reinforcement, educators' implementation and farmers' practice. Specifically, The Silver Wings shows the charm of this concept for understanding China by specifically examining the practice of the family system and the related etiquette system of Han people under the guidance of teachings found in the text Wen Gong Household Rituals (Wengongjiali, 文公家礼) (Du Jing (杜靖), 2012a, b). However, as far as the practice of the traditional ancestor sacrifice ritual is concerned, the process of enculturing grassroots society was interrupted in the Maoist era. It was not until the advent of "reform and opening up" that it was restored. Thus, the family of The Golden Wing is flying once again; that Is why the second book about the family is called "The Silver Wings". 2

Through this work, we know that the practice of Chinese farmers' family-lineage system is actually from Chu Hsi (朱喜) and other great Confucian scholars' thoughts and system design. Because of the long-term cultural practice process, which is "the invention of philosophers, strengthened by the politicians, implemented by the educators and the practiced by farmers” (Zhuang Kongshao (庄孔韶), 2020: 277), a resilient cultural concept is created in the hearts of Chinese farmers. When the external environment is unfavorable, the idea of family-lineage system is kept deep inside, but once the external conditions allow, the idea is immediately externalized into a visible etiquette practice, found, of course, also in the daily behavior and life (Du Jing (杜靖), 2011). Zhuang's view on the origins of the Chinese family-lineage system is quite different from that proposed by Maurice Freedman. According to Maurice Freedman, Chinese lineages are like a corporation, created to satisfy the function of reality (Maurice Freedman, 1958; Maurice Freedman, 1966; David Faure, 2007: 1). In the view of The Silver Wings, satisfying social function is not a primary factor for Chinese family-lineages; it is actually a matter of cultural design and concept practice.

Anthropology has been present in China from the west for a hundred years. Within that period, Zhuang Kongshao and his disciples adopted the concept of Chinese native culture (Du Jing (杜靖), 2012a, b; Chen Jinguo (陈进国, 2017: 97105; Du jing (杜靖), 2018, 2020), while most other anthropologists in China have referred almost exclusively to Western anthropological definitions of culture. ${ }^{3}$ This

\footnotetext{
${ }^{2}$ After the reform and opening up, and because of the cultivation and trade of tremella fungus, the descendants of the Golden Wing family have become rich again.
} 
cultural view naturally leads to a unique methodological perspective, that is, to pay attention to both the interactive relationship between classical elite literature and folk customs, and to "the look-back method" (Zhuang Kongshao 2000: 479) proposed by Zhuang Kongshao, namely, the research method viewed from the grassroots to the top (Zhouhong, 2000). Some China studies scholars outside China insist on observing China from the perspective of "Sinicization" (Ho, 1967, 1998; Harrell, 1995: 2-207), while other Western scholars firmly oppose the dimension of "Sinicization", they think that this idea of studying China from the center of the Han people's standpoint is full of a kind of discourse of hegemony, regardless of the feelings and initiatives of the non-Han people in China (Rawski, 1996; Crosley, Helen F. Siu, etc., 2006: 124). Yet the "Confucianism" project presented in The Silver Wings is not completely such a cultural picture (Zhuang Kongshao, 2012; Dujing, 2015).

Looking at the hundred years of Sinological studies, purely literary-based Sinology research, and the experience-oriented research are separated from each other. The Silver Wings breaks through their boundaries and realizes a cross-reference reading and understanding between literature and experience. This shows the maturity of China studies driven by the author.

As far as the mainstream of anthropology throughout the world is concerned, positivism and rationalism are the basis of anthropology. Almost all anthropologists pay attention to normative fieldwork and logical exposition. However, there are also many blind spots in over-reliance on normative fieldwork. For this reason, Professor Zhuang Kongshao wanted to make up for the neglected part of anthropological academic practice in regard to fieldwork, and he made culturally intuitive observations on some specific scenes with "Cognition without analysis or reasoning "(tiren, 体认 $)^{4}$ and insight. Zhuang believes that Chinese intuition is shared by the elite and the public. It's a cognitive comprehension (wu, 悟), an instant, perceptive leap from the beginning directly to the end. There are all kinds of intuitions, such as mathematical intuition and geometric intuition, but what Zhuang is looking at is cultural intuition, including intuitions of relationships between people, situations, and the process across

\footnotetext{
${ }^{3}$ In addition to the concepts of culture, other Chinese anthropologists have also tried to theorize some of the concepts that are native to China. Such as li(礼), qi(气), tsu(族), mianzi(面子), renqing(人情), etc. In Chinese culture, li does not simply refer to ritual, but also includes gifts, favors, obligations, and hierarchical,etc. Qi, the source of all things, is one of the most important and fundamental concepts in ancient Chinese philosophy. Tsu means Chinese lineage. Mianzi is not the face, but contains dignity, prestige and other connotations. Renqing, includes emotion, rights, obligations and other connotations. However, these concepts are not keywords in the whole discipline of anthropology, and they cannot be compared with the status of cultural concepts.

${ }^{4}$ Namely, the realization without logical analysis, which happens in Chaos (混沌)of thought. Chaos is a primeval state of universe according to ancient Chinese philosophy and folk idea, not separated at this time. Zhan Ruoshui(湛若水), a philosopher who lived in the Ming dynasty, said that even at any time and any place, one can feel and recognize the laws of nature within oneself. Seeing in the concrete, “Showing the students six words” of Zhan Ruoshui (“随处体认天理, 六字千圣同行。万里一心感应, 虚灵中正观生”一—示学六言赠六安潘汝中黄门》, “吾所谓体认者, 非分已发未发, 未分动静。所 谓随处体认天理者, 随已发未发, 随动随静, 盖动静皆吾心之本体, 体用一原故也”). In other words, the result of cognition is not based on the concrete analysis of external phenomena, events, rituals, characters behaviors, etc. It was grasped suddenly in the inner world, not make a careful and detailed analysis.
} 
the field. Zhuang maintains that anthropological fieldwork often presents situational intuition, and so his explorations have been in this area, including the groups, occasions, and characteristics of cultural intuition. In terms of text expression, he has also realized the situation of using standard academic thesis with the traditional Chinese writing method of literature and history. Such intuitive wisdom is not inspired by the West, but deeply rooted in traditional Chinese literature.

The traditional Chinese intuitive thinking is very developed and has a long history. It is different from the epochè found in Western phenomenology. For example, in Chuang-tzu's "comprehend Tao without the help of phenomenological analysis "(tidao, 体道), " comprehend Tao without the aid of hearing" (wendao, 闻道) ${ }^{6}$ and “comprehend Tao without the aid of vision “(dudao, 睹道), ${ }^{7}$ Chu Hsi's "naturally wake up” (“buzhibujue, ziranxingwu”, “不知不觉, 自然醒悟”), ${ }^{8}$ etc.. These concepts are all about intuitive thinking. "It's an experimental and exploratory way of writing

\footnotetext{
${ }^{5} \mathrm{Tao}$ (道), without form, does not act (无为无形). One can get the Tao, but can not see or hear the Tao; We can comprehend the “Tao “, but we can't get the “Tao "by means of teaching 《《庄子.大宗师》云, “可传而不可授, 可得而不可见”; 《庄子.秋水》云, “可以言论者, 物之粗也; 可以意致者, 物之精 也。言之所不能论, 意之所不能察致者, 不期精粗也”). Before the Tao, any words and knowledge are powerless, there is only through the spirit to understand it. Sometimes we have to forget about our bodies in order to experience the Tao of the inner world. so, Chuang-tzu said, "you have to forget your looks and your appearance for moral integrity and natural instincts(de) to grow” (《庄子. 德充符》云, “德 有所长而形有所忘”). It can be seen that “tidao"(体道) can be realized without the help of phenomenological analysis.

${ }^{6}$ Contrary to the literal meaning of the word(implying hearing the Tao), Wen Dao means that we cannot achieve the Tao only through hearing. If our ears are full of sound, we can't realize the Tao, so, we must achieve inner emptiness(心斋). Seeing things in the concrete, “Chuang-tzu-Ren Jian Shi”(庄子.人 间世》云, “无德之以耳而听之以心, 无听之心而听之气。耳止于听, 心止于符。气也者, 虚而待物者 也。唯道集虚。虚者, 心斋也”).

${ }^{7}$ Dudao is similar to the meaning of Wen Tao, namley that the Tao is not obtained through the analysis of the phenomenon provided by eyes and vision (《庄子.天地》说, “视乎冥冥, 听乎无声。冥冥之中, 独 见晓焉, 无声之中, 独闻和焉”; 《庄子.则阳》云, “目者道之人, 不随其所废, 不原其所起, 此议之所止”). The inner world must be left empty and quiet, and it takes a man to awake to Tao.

${ }^{8} \mathrm{Chu} \mathrm{Hsi}$ believed that a little bit of accumulation in the inward world, rather than relying rational analysis, would allow one to come to realize the truth naturally(See "Zhu Zi Yu Lei", volume 10). (《朱 子语类》卷十:“积习既多, 自当脱然有贯通处, 乃是零零碎碎凑合将来, 不知不觉, 自然醒悟”)
} 
in cultural anthropology," Zhuang said. His research has been fully appreciated by scholars George Marcus and Michael Fischer. In combination with a western historical work, Marcus said, "and we say it is exciting because every historian knows intuition is important to interpretation. But it's unspeakable as a logical method. So it was a counter-cultural point. Professor Zhuang suffered and tried to get published because you know considering the gentleman... Even though everyone knows that intuition is a very important aspect of interpretation." 9 Through the investigation of Zhuang Kongshao's academic practice, we understand that intuition has become a new criterion for the deep success of field research. Indeed, only those who know the fields well have intuition. Otherwise, like looking at flowers while riding a horse (zoumaguanhua, 走马观花), in other words, when having a superficial view, during fieldwork, how can we have intuition?

Here, we can see that The Silver Wings provides a reinterpretation and critique of the epistemology of Western anthropology, that is, scientific ethnography, with epistemology based on the "subject-object dichotomy" established by René Descartes. This epistemology holds that there is a clear boundary between the subject and the object of cognition, and the subject believes that it has the ability to know objects. Specifically, knowledge is produced through logical methods of analysis, induction, deduction and synthesis. However, Chinese intuitionism is a kind of way of thinking pursuing a state that "the cognitive subject and object are in a mixed or fuzzy state with each other"(wuwoliangwang, 物我两忘), and not in a clear sense of reason. Chuang-tzu said, "forget the trap as soon as the fish is caught (deyuwangquan,得鱼忘鉒) “Language, sound and character (wenzi, 文字) are often infected by secular values, power and ideology, thus, from Chuang-tzu's point of view, only by discarding this "trap" (such as language, sound and character, etc.) can we get the "Tao". That's intuition in Chinese culture. The epistemology of Lao tze-Chuang tzu philosophy (Lao zhuang zhexue, 老庄哲学) advocates the sudden enlightenment (dunwu, 顿悟). The same is true of the Chan Buddhist sect's teaching. Therefore, conclusions or opinions obtained by intuition are traceless, in that

\footnotetext{
${ }^{9}$ There remarks are from a November 28, 2019 speech by George Marcus at the "Multi-disciplinary Experiment of Painting Anthropology: International Symposium and Anthropology Painting Exhibition" at Yunnan University. In England, even in the whole Western world, only the gentleman's manners and style are proper and graceful, therefore, George Marcus used this phrase "because you know considering the gentleman" to refer to the writing style of the Silver Wings and problems in publishing this book. As we know, academic works have their own writing styles and norms. Although, some of the chapters of "The Silver Wings "are strictly academic, the style in which they are written is like that of novels or prose essays, which is unseemly in the eyes of the intellectual and publishing circles. George Marcus is the representative personage of the "writing school" in Western anthropology, so of course, he can accept this style of writing, and can understand the hardships and pains of publishing this book in the West. Over the past decade or so, professor Zhuang Kongshao has often told me about his troubles in the translation process that took more than 20 years, due to the fact that the publisher asked him to rewrite it into a standard and rigorous western paper. Zhuang refused to change the style of the original works, and in the end he was successful. If we look back, we will find that the publication of Lin Yuehhwa's The Golden wings did not encountered such setbacks. Stylistically, The Golden Wings is a novel, which frees it from some of the ordinary rules of scientific procedure, not least from the obligations of documentation which normally weigh upon the sociologist or historian. With the help of Bruno Lasker and William L.Holland of the Institute of Pacific Relations, The Golden Wings was soon published in the West.
} 
we can't find the right way for it to manifest itself. This is what Song Dynasty's Yan Yu (严羽) wrote, “Creation requires a flash of inspiration, not a rational explanation” (“lingyanguajiao, wujikeqiu”, “羚羊挂角, 无迹可求”). Through the work of ethnography, rethinking the epistemology of West anthropology is rare in the history of Chinese anthropology since the twentieth century. This is the flash point of The Silver Wings.

Here, I would like to point out that we should not interpret The Silver Wings as a closed and isolated text, because at the same time Zhuang was undertaking fieldwork and writing the book, and during follow-up activities, the author shot two anthropological documentary films respectively: Dragon Boat Festival and Winter Solstice of The Golden Wing Valley, covering more than 30 years. We must put the written text of The Silver Wings and the two anthropological films together in a semantic structure, because they have the relationship of defining, interpreting, and generating each other and the relationship of intertextuality. This is a rare achievement in the hundred-year-history of anthropology in China.

Acknowledgements The author thanks the two anonymous reviewers and providers of editorial opinions for their valuable comments, thanks to professor Zhuang Kongshao for his advice, thanks to associate professor Zhang Xiaomin and Dr. Sun Chunlei for providing partial help in the English writing process, and thanks to Miss Chai Chengjing for the literature help.

\section{Author's contributions}

The author is the only contributor to this paper.

\section{Funding}

2011 national foundation for "humanities and social sciences project":"research on the lineage alliance in the Huang-Huai plain since the 16th century"; Project approval No. 11BZS072.

\section{Availability of data and materials}

Not applicable.

\section{Ethics approval and consent to participate}

Not applicable.

\section{Consent for publication}

I authorize your journal to publish my papers, if possible. In the meantime, I also accept the opinion about copyright regulation of your journal. 


\section{Competing interests}

The authors declare that they have no competing interests.

\section{References}

Chen Jinguo (陈进国). 2017. Facing kalpa: Field Studies of Contemporary Chinese Soteriological Religions(《救劫:当代济度宗教的田野研究》). Beijing: Social Sciences Academic Press (北京:中国社会科 学出版社).

Crosley, Pamela Kyley, Helen F. Siu, and Donald S. Sutton. 2006. Introduction. In Empire at the Margins: Culture, Ethnicity, and Frontier in Early Modern China, ed. Pamela Kyle Crosley, Helen F. Siu, and Donald S. Sutton. California: University of California Press.

Du Jing (杜靖).2011. "Idea first” and Social Research of Han People -- Zhuang Kongshao's “Idea View” in Anthropological Practice(《理念先在与汉人社会研究——庄孔韶人类学实践中的“理念观”》). National Forum (《民族论坛》, Academic Edition)(12): 24-32.

Du Jing (杜靖). 2012a. “the Cultivation of Confucianism” and the Cognition of China -- the "Cultural View" in Zhuang Kong Shao's Anthropological Practice(《“儒学教化”与认知中国一一庄孔韶人类学实践中 的“文化观”》). National Forum (《民族论坛》, Academic Edition)(1): 29-37.

Du Jing (杜靖). 2012b. jiu tsu and Chinese Rural society: A fountain Model of the Patriarchal System in the Han People world (《九族与乡土: 一个汉人世界里的喷泉社会》). Beijing: Intellectual Property Publishing House CO., Ltd (北京:知识产权出版社).

Du Jing (杜靖). 2015. On the "Sinicizing" of Overseas Sinology and Its Debate: the Cultural Formation as a Chinese Space(《海外中国学“汉化”中国之论争: 空间中国的文化生成》), Academic Research(《学术 研究》)(11): 94-102.

Du jing (杜靖).2018. War, Migration, Rehabilitation of origin and Recreation of Clan: Take the Minshi Clan of Suzhou, Anhui from the 12th to the 15th Century as an example(《战争、迁徙、复业原籍与宗族再 造: 以12-15世纪的安徽宿州闵氏宗族为例》), Social history studies(《社会史研究》)(6):1-33.

Du jing (杜靖). 2020. Swing between Countries and Relatives: the Historical Process and Cultural Practice of a Han Village Lineage in North China(《在国家与亲属间游移———华北汉人村落宗族的历史过 程与文化实践》)(to be published soon). Hangzhou: Zhejiang University Press.

Faure, David. 2007. Emperor and ancestor: State and lineage in South China. Stanford: Stanford University Press.

Freedman, Maurice. 1958. Lineage Organization in Southern China. London School of Economics, monographs on social anthropology, no.18. London: The Athlone press.

Freedman, Maurice. 1966. Chinese Lineage and Society: Fukien and Kwangtung, London School of Economics, monographs on social anthropology, no.33. London: The Athlone Press.

Harrell, Stevan. 1995. Introduction: Civilizing projects and the reaction to them. In Cultural encounters on China's ethnic Fronties, ed. Stevan Harrell. Seattle: University of Washington Press.

Ho, Ping-Ti. 1967. The significance of the Ch'ing period in Chinese history. Journal of Asian Studies 26 (2): 189-195.

Ho, Ping-ti. 1998. In defense of Sinicization: A rebuttal of Evelyn Rawski's "Reenvisioning" the Qing. Journal of Asian Studies 57 (1): 123-155.

Huang Yinggui (黄应贵). 1983. the Development of Anthropology in Taiwan since the restoration (《光复以 来台湾地区人类学的发展》). Bulletin of the Institute of Ethnology, Academia Sinica(《中央研究院民族 学研究所集刊》) (55): 105-146.

Lin Yueh-hwa (林耀华). 2000. A study of lineage in Yixu Village(《义序的宗族研究》). Beijing: Life. Reading. New knowledge Sanlian bookstore (北京:生活·读书·新知三联书店).

Luo Guanzhong (罗贯中). 2010. The Romance of The Three Kingdoms(《三国演义》). Beijing: People’s Iiterature Publishing House (北京: 人文学出版社).

Rawski, Evelyn S. 1996. Reenvisioning the Qing: The Signification of the Qing Period in Chinese History. The Journal of Asian Studies 55 (4): 829-850.

Tang Meijun (唐美君). 1976. Anthropology in China(《人类学在中国》). Human and Culture(《人类与文 化》) (Taipei: Institute of Anthropology and Archaeology, Taiwan University)(7):9.

Wang Jianmin (王建民). 1997. The History of Ethnology in China (Volume I)(《中国民族学史 上卷》). Kunming: Yunnan Education Press (昆明:云南教育出版社). 
Wang Jianmin (王建民), Zhang Haiyang, Hu Hongbao. 1998. The History of Ethnology in China (Volume II) (《中国民族学史下卷》). Kunming: Yunnan Education Press (昆明:云南教育出版社).

Yueh-hwa, Lin. 1947. The Golden Wing: A Sociological Study of Chinese Familism. New York: Oxford University Press.

Zhou Hong (周泓). 2000. The Sliver Wings: A New Probe into the Methodology of Anthropology(《银翅: 人 类学方法论新探》). Journal of Guangxi University for Nationalities(《广西民族大学学报》,Philosophy and Social Science Edition)(1):138-140.

Zhuang Kongshao (庄孔韶). 2000. The Silver Wings - Local Society and Cultural Changes in China. Beijing: Life. Reading(《银翅:中国的地方社会与文化变迁》). Beijing: Life. Reading. New knowledge Sanlian bookstore (北京:生活·读书·新知三联书店).

Zhuang Kongshao (庄孔韶). 2012. An Examination of the Process of Early Confucianism -- An Anthropological Study of the Interdisciplinary Issues in Ancient and Modern Times(《早期儒学过程检视一古 今跨学科诸问题之人类学探讨》). Anthropological Research(《人类学研究》) (Beijing: Intellectual Property Press)(1): 1-44.

Zhuang Kongshao (庄孔韶). 2020. Pass-Through Moralization, Power, Cultural Adoption and Emotion: A Summary of Multi-Spots Research of Chinese society(《过化、权力、采借与情感——国汉人社会 多点研究归纳》). Journal of South-central University for Nationalities(《中南民族大学学报》, Humanities and Social Sciences)(3):38-51.

\section{Publisher's Note}

Springer Nature remains neutral with regard to jurisdictional claims in published maps and institutional affiliations. 